Article

\title{
Is Parking in Europe Ready for Dynamic Pricing? A Reality Check for the Private Sector
}

\author{
Mark Friesen ${ }^{1}$ and Giuliano Mingardo ${ }^{2, *}$ (C) \\ 1 QUINTA Consulting, D-60323 Frankfurt, Germany; mark.friesen@quinta-consulting.de \\ 2 Erasmus Centre for Urban, Port and Transport Economics, Erasmus University Rotterdam, \\ 3062PA Rotterdam, The Netherlands \\ * Correspondence: mingardo@ese.eur.nl
}

Received: 27 January 2020; Accepted: 26 March 2020; Published: 31 March 2020

check for updates

\begin{abstract}
Both Revenue Management (RM) and Dynamic Pricing (DP) are common practices in many industries—e.g., airlines and hotels—but they are still relatively unknown in the parking sector. In Europe, with the exception of for airport parking and in some pilot tests, DP is rarely used by private parking operators or local authorities. The main objective of this conceptual paper is to set an agenda for introducing DP in the private parking sector at a larger scale. After a short review of the existing academic and gray literature, we describe the requirements and instruments that parking companies need to make use of RM. Next, we shortly report on the major existing and/or planned DP parking schemes in Europe. We continue by providing a comprehensive reality check discussing the major challenges the sector faces to apply DP. We conclude by suggesting a road map for private parking operators to successfully implement RM and DP. Finally, we give some indications for future research.
\end{abstract}

Keywords: parking; revenue management; dynamic pricing; road map

\section{Introduction}

Revenue Management (RM) and Dynamic Pricing (DP) are common pricing practices in many industries—e.g., in the airline and hotel industry—but they are still relatively unknown in the parking sector. We define RM according to Kimes as the "[ ... ] process of allocating the right type of capacity to the right kind of customer at the right price so as to maximize revenue or yield" [1] (p. 15), with DP being "[ $[.$.$] a method whereby the available price changes dynamically over time due to changes in$ demand/capacity/availability" [2](p. 118). In Europe, with the exception of airport parking and some pilot tests, DP is rarely used by private parking operators.

In the last decade, the parking sector has witnessed the introduction of several technological innovations: dynamic information systems, mobile apps to find, pay and (sometimes) reserve onand/or off-street parking, automated number plate recognition (ANPR) systems, sensors, and cameras to enforce paid parking. These innovations have influenced motorists in the way they make use of parking, local authorities in the way they implement parking policies, and operators in the way they manage their parking facilities.

However, pricing schemes in parking have evolved at a slower pace if at all. On the one hand, initial forms of RM have largely been applied by the majority of private parking operators: differentiated tariffs according to the time of the day or day of the week, according to the length-of-stay (short- vs. long-term parking), "early bird" or "daily" tariffs, etc. On the other hand, DP is almost absent in the private parking sector apart from some recent pilot tests in Germany, France, or Norway. While the German APCOA Group has initiated some pilot tests to implement DP in bigger German cities, Belgium Interparking Group has started a pilot test for DP in the French city of Nimes. While APCOA's 
DP model includes up to five different tariff levels for short-term parking depending on the occupancy level of the car park, Interparking's DP model is slightly more advanced since it is able to consider more input variables, e.g., the arrival day, time of arrival, and length-of-stay. Up to 256 different price lists are theoretically applicable $[3,4]$.

Another private sector which had made some progress in implementing DP at a larger scale are European airports. With the advent of pre booking systems for airport parking, operators were able to segment their customers based on their time or price elasticity and offer them a customized parking product at different prices depending on the lead time, length-of-stay, or occupancy level of car parks [5,6]. At present, very few local authorities have introduced DP schemes. With the exception of airports and some cities such as San Francisco [7] or Madrid [8], there are only few examples of cities that have already applied DP or RM for on- and/or off-street parking at a larger scale. Table 1 presents an overview of European cities that have implemented, or are planning to implement, some forms of RM or DP in parking.

Table 1. Examples of European cities having implemented or having announced to implement Revenue Management (RM) or Dynamic Pricing (DP) in parking.

\begin{tabular}{|c|c|c|c|c|}
\hline City & Facility or Area & On-Street/Off-Street & Operator & Start \\
\hline Madrid & City center & on-street & Private & 2006 \\
\hline Basel & City center & on-street & not yet decided & 2020 \\
\hline Oslo & Gardermoen Airport & off-street & Private & 2018 \\
\hline London & $\begin{array}{c}\text { Queensway Car Park } \\
\text { Baywater }\end{array}$ & off-street & Private & 2008 \\
\hline Moscow & City center & on-street & Municipality & 2012 \\
\hline San Sebastian & City center & on-street & Municipality & 2013 \\
\hline
\end{tabular}

The main objective of this paper is to set an agenda for introducing RM or DP in the private parking sector at a larger scale. This is a conceptual paper inspired by grounded theory: our research is performed by observing and analyzing already existing information on parking pricing based on the author's own professional experience, the literature, and existing real case studies.

The reminder of this paper is structured as follows: after a short review of the existing literature, we describe the requirements and instruments private parking companies need to make use of RM or DP. Next, we shortly report on the few existing examples of RM and/or DP in the private and public parking sector. We continue with providing a qualitative reality check discussing the major challenges the private sector faces to apply DP mechanisms. We conclude by suggesting a road map for private parking operators to successfully implement RM and DP and finally give some indications for future research.

\section{Previous Research}

Already in 2006, Arnot and Inci [9] suggested that, to reduce welfare loss, parking rates should not be fixed to linear fees. Approximately a decade later, Inci [10] observed that cities were able to apply $\mathrm{RM}$ and DP to parking through the application of smart parking systems in the attempt to achieve the 85 percent optimal occupancy rate level, as suggested by Shoup [11]. Yet, there is little academic literature on these topics.

Considering the application of RM in the parking sector, Guadix [12] suggests an application model and, based on occupancy data, a demand forecast which is based on future drivers. The forecasts are used to distribute car parks' available capacity at different time slots, taking into account different promotional offers, parking behavior, and demographic factors. Teodorovic and Lucic [13] discuss the concepts of parking reservation and parking RM proposing a special parking space inventory control system, which can accept or reject a driver's request for parking. The system assumes that (future) traffic arrival patterns are known to the parking operator. Results suggest that it is possible to maximize revenues. Gaudix et al. [14] on the contrary propose to make use of deterministic and stochastic models 
to optimize the revenue of a parking lot under the assumption that individual and subscribed drivers exist. Madsen et al. [15] study demand elasticity for on-street parking in Copenhagen analyzing data for the period from 2008 to 2011. They suggest that a spatially differentiated parking fee is necessary to create an optimal parking pattern. Earlier, Kelly et al [16] found an average price elasticity of demand of -0.29 , analyzing on-street parking data in Dublin.

The literature on DP applied to parking seems to be slightly richer, especially over the last five years. Qian and Rajagopal [17] investigate the use of dynamic parking fees to better manage the parking demand generated by morning commuters. Using linear programming techniques, they show that the best system performance is achieved by pricing the preferred location to such a level that keeps occupancy levels around 85-95 percent. As a result, they provide empirical evidence for the optimal occupancy ratio rule of thumb suggested by Shoup [11] and used it as a reference for many other cities. Mackowski et al. [18] develop a dynamic non-cooperative bi-level model to set real-time parking prices that eliminate cruising, suggesting that their model could fit a parking management system.

Zheng and Geroliminis [19] develop a macroscopic fundamental diagram multimodal traffic modeling approach that applies different pricing strategies for parking. Their model, that incorporates price competition between parking operators, suggests that a dynamic parking pricing system is effective in order to reduce cruising and congestion.

Tian et al. [6] formulate a DP model for parking reservations as a stochastic dynamic programming, in which the optimal price maximizes the operator's expected revenue. They assume a Poisson process for the arrival requests with the arrival intensity being influenced by DP. They show that a DP scheme can generate significant improvements in revenue and inventory during peak periods while also significantly reducing travelers' cruising costs.

Next, Pierce and Shoup [7] analyze the data generated in the first year by SFpark, the program introduced by the city of San Francisco to adjust on-street parking fees based on different occupancy levels. This is the first prominent example for the application of DP to on-street parking at a larger scale in the world. The authors focused on price elasticity of demand, finding an average value of -0.4 with large variations according to the time of the day, the day of the week, and the location within the city.

Finally, Fichman [20] performs an analysis of the DP parking system implemented in Pittsburgh (USA), finding evidence for a change in drivers' behavior in response to dynamic fees. The author clearly found a time lag between the change in behavior and the adjusted prices, suggesting the important role of communication to achieve an optimal situation.

\section{Basics of Revenue Management and Dynamic Pricing}

The focus of this section is to shortly explore the historical background as well as basic theoretical requirements and instruments for the application of RM and DP.

\subsection{Backgroung, Definition and Requirements}

Following the structural changes that took place in the late 1960s and 1970s in the air traffic sector-i.e., the implementation of the computer aided reservation system (CRS), the introduction of special fares, the deregulation of the US-American air traffic in 1979 and the advent of low-cost carriers-most airlines dismissed their rigid tariff structure and introduced DP and inventory management.

There have been several attempts to define RM. Liebermann [21] (p.34) describes the wide range of definitions with the following: "[ ... ] if you ask ten hoteliers what it is, you are apt to get at least five, and possibly ten, different answers". Kimes [22] (p.15) defines RM of traditional airlines as a "[ ... ] process of allocating the right type of capacity to the right kind of customer at the right price so as to maximize revenue or yield". Following this definition, RM can be seen as a quantitative strategy aimed to assign existing capacities to the demand in order to maximize revenue, under simultaneous price and capacity constraints. 
According to Kimes [22], companies have to meet the following six basic requirements to apply RM:

- Relatively fixed capacities

- Possibility of efficient market segmentation

- Inability to store and perishability of service

- Possibility of advanced booking of service

- Strong fluctuation and uncertainty of demand

- Low marginal sales costs and high marginal production costs.

\subsection{Instruments of $R M$}

The instruments of RM need to be viewed separately from the application requirements. According to Friesen and Reinecke [23], there are five instruments of RM (see Figure 1):

- Data compilation

- Forecasting

- Price steering

- Inventory management

- Monitoring.

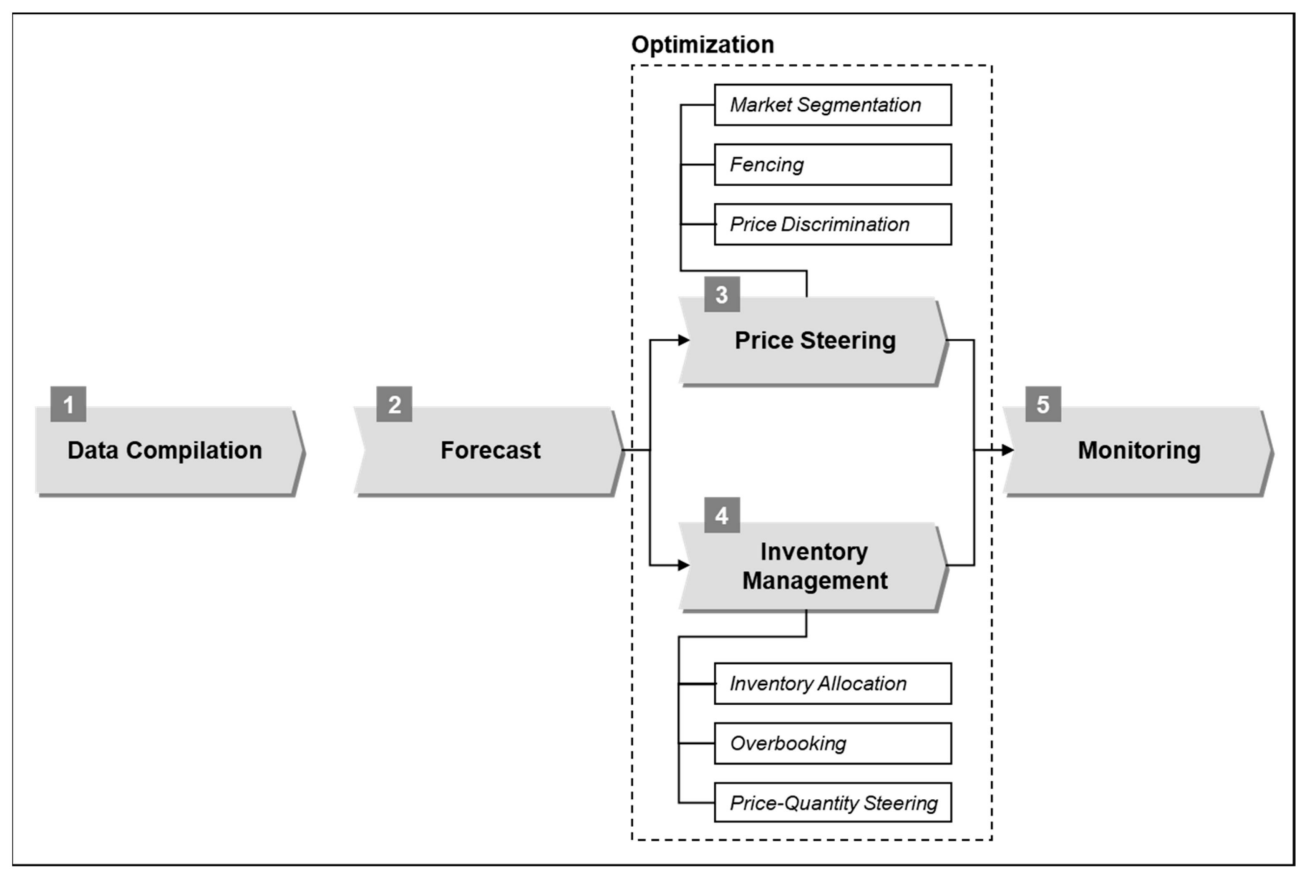

Figure 1. Instruments to implement RM (based on Friesen and Reinecke [23]).

The booking data base serves as the basis to forecast future demand-related behavior, as well as for demand structures. It contains figures on past and current booking data (capacities, tariffs, utilization), structure of demand, past cancellation and no-show rates, competitive data, special occasions and price elasticity. The data base coupled with forecast models provides input for the optimization, divided into price management [steering] and capacity [inventory] management.

Price management first involves a market segmentation based on the heterogeneous willingness-to-pay (WTP) of customers. For example, it is normally assumed that business travelers are price-inelastic, but time-sensitive, while leisure travelers are price-elastic, but not time-sensitive. Based on the identified market segments, rate fences are determined to separate the different classes of 
carriage - e.g., first class, business class, economy class. The different WTP of consumers is the basis for a segmented price discrimination, which aims for skimming off the consumer's surplus.

The fact that segmented price discrimination acts on the assumption of a deterministic pattern of demands necessitates allocation rules. These rules display the course of booking of stochastic demand at optimal revenue. For that reason, price discrimination is complemented by the optimization element of inventory management. In contrast to simple price discrimination including pre-defined price levels for a certain number of seats, RM reacts to the irregularity of air traffic demand by constantly adjusting the number of available seats at different prices [24].

Firstly, the allocation of the restricted capacity within the booking classes and the booking limitations are being identified on the basis of demand forecast models. Companies need to determine whether a booking request is confirmed or is withheld for a full-paying customer later on. In order to solve this operational problem, nesting can be applied-implying that part of the total capacity for the demand for booking classes with a higher revenue potential is being withheld [24,25]. Additionally, another reliable element of capacity management is overbooking. By deliberately selling more seats than actual available capacities, the risk of insufficient capacity utilization is reduced through "no shows"-i.e., passengers who do not show up at departure time - or unplanned "go shows"-i.e., passengers flying on a flight different from that one they had a reservation for. Therefore, overbooking serves as a balance of risk between revenue loss and displaced revenue.

Finally, price-quantity steering-as another substantial element of inventory management-draws on data of price discrimination and product allocation, thus, defining tariff classes to which parts of the capacity are being assigned. Furthermore, both prices and corresponding capacities are being adjusted to the expectations of the course of booking. This adjustment process is already part of the monitoring process, which records the quality of the optimization process as well as making continuous modifications in price and capacity while reporting in real-time to global distribution systems [23].

\subsection{From $R M$ to $D P$}

DP, also known as demand-based, peak-load, or surge pricing, is a pricing strategy that is directly related to price steering within RM. Supported by digitalization, DP found its way from the travel and transport industry into several other sectors such as retail, advertising, or electricity. Based on specific market conditions or customer characteristics, companies set flexible prices for products or services in order to account for fluctuations in demand [2].

Subject to the price elasticity of demand, DP features price increases when demand is strong and price decreases when demand is weaker to stimulate demand. Thus, a better capacity utilization and a higher exploitation of WTP is aimed for. However, DP as it is currently applied does not account for what each individual consumer is willing-to-pay, i.e., personalized DP [2].

While DP is already an established form of price discrimination in the airline industry, in other sectors there is an inherent risk that customers feel they are being treated unfairly. Based on the behavioral concept of price fairness and with almost perfect price transparency, DP could entail negative word-of-mouth, buying restraints, or even customer rejection [23].

In summary, the management of the inventory, not of the price, is paramount for RM involving airlines. Dynamic prices are understood to be a consequence of the strict availability allocation of differently priced seat capacities $[23,26]$.

\section{Application of Dynamic Pricing in the Parking Sector}

While DP is an established form of pricing in many sectors today-e.g., airlines, hotels, rental car companies, and tour operators-the parking industry is clearly lagging behind, both in on- and off-street parking. Even though parking theoretically meets all requirements for the application of RM suggested by Kimes [22]— see Section 3.1—it has to be elucidated why the common practice for short-term parking fees is still to make use of tariff models that are based on hourly fees (or fractions of hours, i.e., 10 or 15 minutes), reaching a daily maximum fee [27]. 
At present, with the exception of European airports and some promising pilot tests established in European cities (see Table 1), there are only few examples of DP applied in the private parking sector. To the best of the authors' knowledge, the two most prominent ones are pursued by public parking authorities, namely San Francisco's SFpark program and Madrid.

SFpark is a demand-responsive parking pricing project introduced in a pilot area by the city of San Francisco (USA) in 2011. The parking meters adapt the parking fee according to location, time of the day, and day of the week with the goal of keeping 15 percent of spaces available at any time. The scheme applies to approximately a quarter of all metered parking spaces of the city and to three quarters of all city-owned parking garages [28]. A project evaluation [29] suggests that DP applied to parking generates benefits for both the local authority and drivers: average parking rates were 1 percent lower on average, while the availability of parking improved and cruising (and related emissions) decreased.

The city of Madrid (Spain) introduced a DP system in July 2014 in which the parking fee varies according to the type of vehicle and actual demand. The second aspect is that this system is an example of DP application for on-street parking fees. Drivers pay a reduced fee of 20 percent or 10 percent when the occupancy level is below 30 percent and between 30 percent and 60 percent, respectively; the regular fee is applied when the occupancy ratio is between 60 percent and 85 percent; when the capacity utilization is between 85 percent and 95 percent or above 95 percent, drivers pay 10 percent or 20 percent more [30].

Airports were among the first in the private parking sector to implement DP and RM. Driven by intense competitive pressure of off-airport parking suppliers, a strong demand of digital-savvy customers to pre-book parking spaces in advance, and technological leaps in pre-booking technology, the first airport operators, especially in Oceania and Europe, started implementing DP and RM around ten years ago.

Big European hub airports like London-Heathrow, Amsterdam Schiphol, or Oslo Gardermoen are now making use of many instruments of RM and DP as described in Section 3. With the help of either internally developed RM systems or external RM systems, suppliers that are specialized in car parking airports use DP mostly for their pre-booking businesses to better control their inventory and account for demand peaks, e.g., during the holiday season [6]. Hub airport operators also expect their car parking revenue to be increased by applying RM and/or DP. Interestingly, American airports, e.g., the New York Airport Authority or Denver Airport are still lagging behind in this area but are investing heavily to catch up with their European peers.

Mid- to smaller-sized airport operators in Europe often do not have the resources and funding to decide to implement RM or DP for their car parking businesses. Hence, instead of using professional RM systems, those airports make use of the possibility to implement multiple price buckets in their pre-booking systems, i.e., inventory buckets of a car park priced at different tariff levels. Even though this form of price discrimination does not fully exploit the maximum WTP of customers, it represents a promising way to overcome the 'one-size-fits-all' pricing approach still prevailing in the private and public parking sectors [27].

Every vacant on- or off-street parking lot represents foregone turnover and profit for private and public parking operators alike and accordingly an inefficient use of scarce (urban) space. Dynamic steering of tariffs combined with active inventory control gives the parking sector the unique chance to catch up with other industries, e.g., the airline industry, which have been using this pricing mechanism very successfully for decades (see Section 3).

In the next section, we describe the preconditions that have to be met for DP to be applied in the private parking sector in Europe.

\section{Is the Private Parking Sector in Europe Ready for Revenue Management and Dynamic Pricing?}

In this section, we first prove that parking, as a service, meets all the theoretical requirements of RM (based on Kimes [22]). Second, we discuss whether parking, as a sector, has all the instruments 
available to implement RM [12,23]. Third, we conduct a reality check discussing the major challenges the private sector in Europe faces to apply DP mechanisms.

\subsection{Requirements}

Table 2 provides an overview of the basic requirements of RM applied to the private parking sector in urban areas. It clearly shows that parking is a service that meets all theoretical requirements [12]. Capacity is fixed in the short run. Motorists, like airline passengers, have different reasons to travel and, accordingly, can be segmented into different customer groups. Clearly, an unused space at a specific time and place cannot be used at another time and location, making storage of a parking space literally impossible. Advanced selling and/or booking is already a reality in parking, though this is often constrained to event-related activities—e.g., booking a parking space for a theatre visit or a cruise trip. As suggested by many authors $[7,16,31,32]$, demand for parking varies across the day of the week, the week, the year and across different locations. Finally, while the incremental cost of selling an additional parking spot to a motorist is close to zero, the cost of providing an additional space is related to large investments.

Table 2. Requirements for RM applied to on- and off-street parking in urban areas.

\begin{tabular}{|c|c|c|}
\hline $\begin{array}{l}\text { Requirements for } \\
\text { Application of RM }\end{array}$ & Fulfilment in the Parking Sector? & Explanation \\
\hline Limited capacity & Yes & $\begin{array}{l}\text { In urban areas, parking supply is fixed } \\
\text { in the short-term and any car park has a } \\
\text { limited number of parking lots }\end{array}$ \\
\hline $\begin{array}{l}\text { Possibility for market } \\
\text { segmentation }\end{array}$ & Yes & $\begin{array}{l}\text { Motorists can be segmented, for } \\
\text { example based on reason of the trip (i.e., } \\
\text { work, leisure ... ) or the length of stay } \\
\text { (short- vs long-term parking) }\end{array}$ \\
\hline $\begin{array}{l}\text { Inability to store and } \\
\text { perishability of service }\end{array}$ & Yes & $\begin{array}{l}\text { If a parking lot is unused at a specific } \\
\text { time, it cannot be stored and used at a } \\
\text { later moment }\end{array}$ \\
\hline $\begin{array}{l}\text { Possibility of advanced } \\
\text { selling/booking }\end{array}$ & Yes & $\begin{array}{l}\text { Thanks to new technological } \\
\text { developments, pre-booking is already a } \\
\text { reality in parking }\end{array}$ \\
\hline $\begin{array}{l}\text { Strong demand } \\
\text { fluctuation }\end{array}$ & Yes & $\begin{array}{l}\text { Demand for parking fluctuates across } \\
\text { the day, week, and/or month }\end{array}$ \\
\hline $\begin{array}{l}\text { Low marginal sale costs } \\
\text { and high marginal } \\
\text { production costs }\end{array}$ & Yes & $\begin{array}{l}\text { The incremental cost of selling an } \\
\text { additional parking lot is close to zero, } \\
\text { while if capacity is fully utilized, the } \\
\text { cost of an additional unit is very big }\end{array}$ \\
\hline
\end{tabular}

\subsection{Instruments}

Table 3 describes the instruments of RM and its applicability in the private parking sector, which need to be viewed separately from the application requirements. Single transactional data (i.e., on- and offline data) serve as a basis to forecast future demand patterns (e.g., pre-booking lead times, length of stay etc.) as well as demand structures (e.g., short-term vs. long-term parking). The transactional data base together with the forecast algorithm represents the information input for the optimization: price steering and inventory management. Price steering is composed of the ability to differentiate prices for various market segments with an appropriate fencing mechanism. In the private parking sector, both price differentiation and market segmentation are still only rudimentarily used, since the ability to appropriately fence a parking lot is quite limited in a single car park. Inventory management as the second most important pillar of RM is often overseen in the parking industry. There are very few car parks with 24/7 occupancy levels of 50 percent or higher. Surprisingly, not all parking operators 
are aware of the benefits of increasing the occupancy level for a car park's overall profitability. At the moment, only some airport operators and some of the largest private car park operators in Europe apply inventory management to better use their overall car park capacity during times of strong demand, but also during times of weak demand. Monitoring the success of applying RM is crucial in any industry. Hence, for private car parking companies, it should become a routine to continuously extract, clean, mine, and analyze data to be able to regularly review and readjust single instruments of the whole RM process.

Table 3. Instruments for RM applied to on- and off-street parking in urban areas (authors' own elaboration).

\begin{tabular}{|c|c|c|}
\hline Instruments of RM & $\begin{array}{l}\text { Availability in the } \\
\text { Parking Sector? }\end{array}$ & Explanation \\
\hline Data compilation & & $\begin{array}{c}\text { Transactional data is available in every parking } \\
\text { management system (PMS) as the basis to forecast } \\
\text { future demand. However, only few companies still } \\
\text { make use of it. }\end{array}$ \\
\hline Forecasting & & $\begin{array}{l}\text { Plenty of forecasting models are available that can be } \\
\text { applied to the parking industry, but there is hardly } \\
\text { any company or local authority using them. }\end{array}$ \\
\hline Price steering & & $\begin{array}{l}\text { Price discrimination, market segmentation, and } \\
\text { fencing are hardly used in car parking except for by } \\
\text { airports and for event-related activities. }\end{array}$ \\
\hline Inventory management & & $\begin{array}{l}\text { At the moment, only some bigger airports apply } \\
\text { inventory management to better steer the capacity of } \\
\text { their car parks. }\end{array}$ \\
\hline Monitoring & & $\begin{array}{c}\text { Few local authorities monitor the usage of their car } \\
\text { parks, while bigger private parking companies have } \\
\text { a proper monitoring system in place. }\end{array}$ \\
\hline Legend & None & ( Little $($ Medium $\bigcirc$ Higher $\bigcirc$ High \\
\hline
\end{tabular}

\subsection{Reality Check}

Finally, we discuss the major challenges the private parking sector in Europe needs to overcome to make DP a reality (see Table 4). At the moment, European private operators do not feel any urgency to introduce DP, mainly because they might be afraid of possible negative reactions of customers. Even though all private parking operators want to maximize revenues, none dares to be the first to introduce DP on a large scale. They genuinely fear that motorists will simply not accept it [27].

As we have seen in the previous section, there is little experience with DP in parking. Despite the success of SFpark, at present there are only few private parking operators in Europe seriously introducing similar DP schemes.

There is plenty of data available in parking as every paid parking transaction is registered, recorded and stored. The transactional data collected by a typical PMS (Parking Management System)-i.e., date and time of entry and exit, length-of-stay, amount, payment method and oftentimes also the number plate-allows for a comprehensive level of customer segmentation. Yet, few parking operators make use of parking data to understand drivers' behavior and/or to get more insights on customers. Some private operators make more systematic use of the data, but usually for management reports concerning turnover and occupancy ratios [27].

Effective internal and external communication is a key to success if the private parking sector in Europe wants to introduce DP at a larger scale [27]. Parking usually has a bad price image and a questionable reputation among the general public, e.g., spaces are never enough, and it is always too expensive. This bad image has its origin in the fact that private operators always focused on the "how you have to pay for parking" and almost never on "why you have to pay for parking" when communicating with customers. Despite being comparable with many common services such as 
utilities, restaurants, or cinemas, parking companies still have to explain to their customer why they have to pay for this service. Manville [33] (p. 141-142) describes this discussing by "[ ... ] Parking charges are a rent for using space, and the economic benefit of rent comes from collecting it, not in how its revenue is used. [ ... ] Water companies don't meter because (or entirely because) they need to cover costs. They meter to prevent people from turning on the tap and then leaving for hours without turning it off. [ ... ] With parking, somewhere this distinction got lost."

Table 4. Challenges that the parking sector must face to introduce DP.

\begin{tabular}{|c|c|c|}
\hline Challenge & $\begin{array}{l}\text { Readiness Level of } \\
\text { the Parking Sector }\end{array}$ & Explanation \\
\hline Willingness-to-change & & No sense of urgency to implement DP at the moment \\
\hline Experience & & Little experience with DP, mostly in airport parking \\
\hline $\begin{array}{l}\text { Data and customer } \\
\text { insights }\end{array}$ & & $\begin{array}{c}\text { Transaction data on parking patterns available e.g., to } \\
\text { calculate WTP }\end{array}$ \\
\hline Know-how & & $\begin{array}{l}\text { Local authorities and parking operators usually don't } \\
\text { have people with necessary skills available }\end{array}$ \\
\hline Communication & & $\begin{array}{l}\text { Adequate marketing and communication effort is } \\
\text { necessary to overcome fear of losing customers }\end{array}$ \\
\hline Legislation & & $\begin{array}{c}\text { Permission to use DP in parking as long as displayed } \\
\text { when entering a car park }\end{array}$ \\
\hline Legend & $\mathrm{O}$ & one $\bigcirc$ Little $\bigcirc$ Medium $\bigcirc$ Higher \\
\hline
\end{tabular}

Finally, in most European countries, relevant legislation allows parking operators and local authorities to decide which pricing structure to implement [34] and, accordingly, does not represent a big obstacle to overcome when applying DP.

\section{Conclusions: A Road Map for Dynamic Parking Pricing}

To actively implement DP at a larger scale, we suggest for private parking operators in Europe a migration model from the current static, "one-size-fits-all"-pricing model to a more DP scheme through three steps: (i) understand, (ii) evaluate, and (iii) communicate.

First, understanding customer behavior should be the initial step. On- and off-street PMS virtually register every single parking transaction that involves a payment. This huge amount of transactional data should be used to better understand (and predict) drivers' behavior. At the moment, the biggest challenge is that those who are or should be interested in better understanding parking patterns (e.g., parking operators) usually do not have the right level of skills to thoroughly analyze and understand the data; and those who have proper skills to make use of the richness of the data (e.g., PMS providers and mobile pay applications providers) usually are not heavily interested in using or sharing data insights to better understand customers' behavior.

Second, more pilot tests with DP must be carried out, monitored, and evaluated. APCOA's and Interparking's first attempts in Europe as well as SFpark's venture in the US are rare but good examples showing that the introduction of DP in parking yields benefits for everyone. Thanks to the comprehensive and rigorous evaluation performed by the local authority, the SFpark scheme is now enlarged to other areas of San Francisco [35] and other cities are seriously considering introducing DP in parking as well (e.g., Milwaukee [36] in the U.S. and Basel [37] in Europe). A diligent evaluation has to consider the effect of DP on revenue, demand (i.e., occupancy levels, turnover, length-of-stay) traffic flows, competition between different parking locations, and public acceptance.

Third, internal and external communication is the most crucial aspect. Contrary to the airline industry, the paid private parking sector has-as already described-a (relatively) bad image among consumers. Most drivers still find it difficult to understand why they have to pay for a parking space. This bad reputation is one of the key reasons for the fear from private parking operators in Europe 
towards implementing DP in their off-street facilities. To overcome this anxiety, three aspects are crucial from the authors' point of view: (i) how the customer perceives and accepts the rules of pricing (e.g., "the later you book the more expensive the ticket becomes") [23], (ii) how exactly the mechanism of DP works-according to Haws and Bearden [38]) the fairness perception is different for a scenario where the supplier sets prices with customers participating in the price-setting process, e.g., "pay-what you-want", "name-your-own-price" or any kind of auctioning or bidding process., and (iii) how the price discrimination is framed [39].

Finally, we provide some suggestions for further research. First of all, the few existing and recent examples of DP in private parking should be further explored and analyzed. On the one hand, we invite parking operators to share their data with the academic world; on the other hand, academics could put emphasis on the analysis of DP schemes that were recently introduced by some private operators to better understand drivers' behavior and customers' demand patterns. Experimental research could be used to test for (un)fairness perceptions among customers which together with expert interviews could help us to better understand the reluctance of private operators in Europe to implement RM and/or DP in parking.

Author Contributions: Conceptualization: M.F., G.M., Methodology: M.F., G.M., Acquisition and analysis of data: M.F., Writing: M.F., G.M., Reviewing and editing: M.F., G.M. All authors have read and agreed to the published version of the manuscript.

Funding: This research received no external funding.

Conflicts of Interest: The authors declare no conflict of interest.

\section{References}

1. Kimes, S.E. A strategic approach to yield management. In Yield Management; Ingold, A., McMahon-Beattie, U., Yeoman, I., Eds.; Thomson Learning: Padstow, Cornwall, UK, 2000.

2. Krämer, A.; Friesen, M.; Shelton, T. Are airline passengers ready for personalized dynamic pricing? A study of German consumers. J. Revenue Pricing Manag. 2018, 17, 115-120. [CrossRef]

3. Ruh, M. Yield management in Hamburg, Leipzig and Stuttgart. Parking Trend Intern. 2019, 33, 10.

4. Mollaret, G. Un Parking de Nîmes Ajuste Ses Tarifs en Fonction de L'affluence. 2019. Available online: http://www.lefigaro.fr/societes/un-parking-de-nimes-ajuste-ses-tarifs-en-fonction-de-1-affluence20190722 (accessed on 12 November 2019).

5. Friesen, M. Parking still has room to grow. Parking Trend Intern. 2013, 27, 37.

6. Tian, Q.; Yang, L.; Wang, C.; Huang, H.J. Dynamic pricing for reservation-based parking system: A revenue management method. Transp. Policy 2018, 71, 36-44. [CrossRef]

7. Pierce, G.; Shoup, D. Getting the price right. J. Am. Plan. Assoc. 2013, 79, 67-81. [CrossRef]

8. Controlled on-street parking in Madrid. Available online: https://www.group-indigo.com/en/reference/ controlled-on-street-parking-in-madrid/ (accessed on 12 November 2019).

9. Arnott, R.; Inci, E. An integrated model of downtown parking and traffic congestion. J. Urban Econ. 2006, 60, 418-442. [CrossRef]

10. Inci, E. A review of the economics of parking. Econ. Transp. 2015, 4, 50-63. [CrossRef]

11. Shoup, D. The High Cost of Free Parking; American Planning Association: Chicago, IL, USA, 2005.

12. Guadix, J. Practical Pricing for the Car Park Industry. In Revenue Management; Yeoman, I., McMahon-Beattie, U., Eds.; Palgrave Macmillian: London, UK, 2011.

13. Teodorović, D.; Lučić, P. Intelligent parking systems. Eur. J. Oper. Res. 2006, 175, 1666-1681. [CrossRef]

14. Guadix, J.; Cortés, P.; Muñuzuri, J.; Onieva, L. Parking revenue management. J. Revenue Pricing Manag. 2009, 8, 343-356. [CrossRef]

15. Madsen, E.; Mulalic, I.; Pilegaard, N. A model for estimation of the demand for on-street parking. Available online: https://mpra.ub.uni-muenchen.de/52361/1/MPRA_paper_52301.pdf (accessed on 24 August 2018).

16. Kelly, J.A.; Clinch, J.P. Temporal variance of revealed preference on-street parking price elasticity. Transp. Policy 2009, 16, 193-199. [CrossRef]

17. Qian, Z.; Rajagopal, R. Optimal dynamic parking pricing for morning commute considering expected cruising time. Transp. Res. Part C Emerg. Technol. 2014, 48, 468-490. [CrossRef] 
18. Mackowski, D.; Bai, Y.; Ouyang, Y. Parking Space Management via Dynamic Performance-based Pricing. Transp. Res. Procedia 2015, 7, 170-191. [CrossRef]

19. Zheng, N.; Geroliminis, N. Modeling and optimization of multimodal urban networks with limited parking and dynamic pricing. Transp. Res. Part B Methodol. 2016, 83, 36-58. [CrossRef]

20. Fichman, M. An Evaluation of Pittsburgh's Dynamically-Priced Curb Parking Pilot; University of Pennsylvania: Philadelphia, PA, USA, 2016.

21. Lieberman, W.H. Debunking the Myths of Yield Management. Cornell Hotel Restaur. Adm. Q. 1993, 34, $34-41$. [CrossRef]

22. Kimes, S.E. The Basics of Yield Management. Cornell Hotel Restaur. Adm. Q. 1989, 30, 14-19. [CrossRef]

23. Friesen, M.; Reinecke, S. Wahrgenommene Preisfairness bei Revenue Management im Luftverkehr. Mark. Rev. St. Gallen 2007, 24, 34-39. [CrossRef]

24. Botimer, T.C. Airline Pricing and Fare Product Differentiation; MIT: Cambridge, MA, USA, 1994.

25. Belobaba, P. Airline Yield Management: An Overview of Seat Inventory Control. Transp. Sci. 1987, 21, 63-73. [CrossRef]

26. Talluri, K.T.; Van Ryzin, G.J. The Theory and Practice of Revenue Management; Springer: Boston, MA, USA; Dordrecht, The Netherlands; London, UK, 2004.

27. Friesen, M. New customer-centric tariff models-Improved value-based parking for operators and customers alike. Parking Trend Int. 2013, 27, 38-41.

28. SF park. Available online: http://sfpark.org/about-the-project/ (accessed on 24 August 2018).

29. San Francisco Municipal Transportation Agency (SFMTA). 2014. SFpark Pilot Project Evaluation. Available online: http://direct.sfpark.org/wp-content/uploads/eval/SFpark_Pilot_Project_Evaluation.pdf (accessed on 24 August 2018).

30. Portal web del Ayuntamiento de Madrid. Available online: https://espaciocoches. com/tarifas-de-la-zona-azul-en-madrid/ and https://www.madrid.es/portales/munimadrid/ es/Inicio/Movilidad-y-transportes/Circulacion-y-aparcamiento/Servicio-de-EstacionamientoRegulado-Horario-delimitacion-territorial-y-ambitos-diferenciados-/?vgnextfmt= defaultandvgnextoid=6f18e4ce78dd6410VgnVCM1000000b205a0aRCRDandvgnextchannel= b3128fb9458fe410VgnVCM1000000b205a0aRCRD (accessed on 24 August 2018).

31. Milosavljević, N.; Simićević, J. User response to parking policy change: A comparison of stated and revealed preference data. Transp. Policy 2016, 46, 40-45. [CrossRef]

32. Simićević, J.; Milosavljević, N.; Maletić, G.; Kaplanović, S. Defining parking price based on users' attitudes. Transp. Policy 2012, 23, 70-78. [CrossRef]

33. Manville, M. Parking Pricing. In Parking-Issues and Policies; Ison, S., Mulley, C., Eds.; Emerald Group Publishing Limited: Bingley, UK, 2014.

34. Mingardo, G.; van Wee, B.; Rye, T. Urban parking policy in Europe: A conceptualization of past and possible future trends. Transp. Res. Part A Policy Pract. 2015, 74, 268-281. [CrossRef]

35. SF park, Update: December 2017. Available online: http://sfpark.org (accessed on 24 August 2018).

36. Urban Milwaukee. Available online: https://urbanmilwaukee.com/2018/09/13/city-hall-demand-basedparking-meters-coming/ (accessed on 7 September 2018).

37. Badische Zeitung. Available online: http://www.badische-zeitung.de/basel/parkgebuehren-nach-nachfrage-153356514.html (accessed on 24 August 2018).

38. Haws, K.L.; Bearden, W.O. Dynamic Pricing and Consumer Fairness Perceptions. J. Consum. Res. 2006, 33, 304-311. [CrossRef]

39. Weisstein, F.L.; Monroe, K.B.; Kukar-Kinney, M. Effects of price framing on consumers' perceptions of online dynamic pricing practices. J. Acad. Mark. Sci. 2013, 41, 501-514. [CrossRef]

(C) 2020 by the authors. Licensee MDPI, Basel, Switzerland. This article is an open access article distributed under the terms and conditions of the Creative Commons Attribution (CC BY) license (http://creativecommons.org/licenses/by/4.0/). 